\section{'White Rock' and 'White County' Peaches}

John R. Clark ${ }^{1}$ and James N. Moore ${ }^{2}$,

Department of Horticulture, University of Arkansas, Fayetteville, AR 72701

\section{Penelope Perkins-Veazie ${ }^{3}$}

U.S. Department of Agriculture, Agricultural Research Service, South Central Agricultural Research Center, Lane, OK 74555

Additional index words. Prunus persica, fruit breeding, bacterial spot, Xanthomonas campestris pv. pruni

'White Rock' and 'White County' are the second and third white-flesh peach releases from the University of Arkansas peach [Prunus persica (L.) Batsch] breeding program. 'White River' was released in 2002 (Clark and Moore, 2003). The program began in the 1960s (Clark et al., 1999) and included an objective to develop adapted white-flesh peach cultivars for

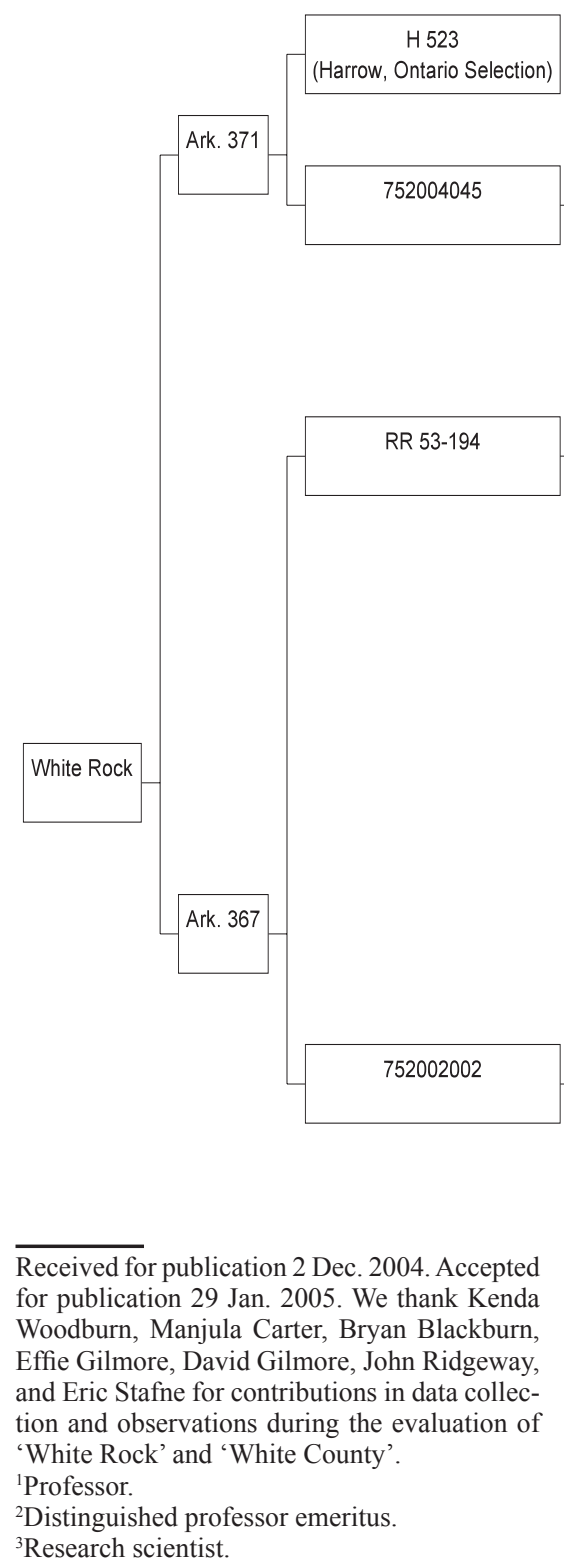

on-farm, local, and shipping sales.

'White Rock' is an early midseason maturity clingstone with nonmelting flesh that is low-acid in flavor, and very firm when ripe and overripe. 'White County' is a midseason freestone with low-acid flavor and firm fruit. These cultivars have moderate to good resistance to bacterial spot [caused by Xanthomonas campestris pv. pruni (Smith) Dye] and should provide high-quality, low-acid options for
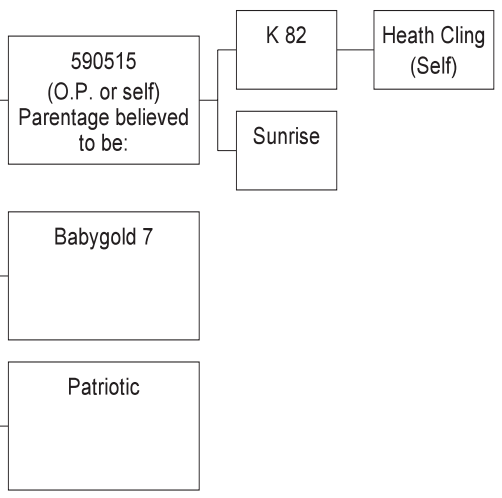

21

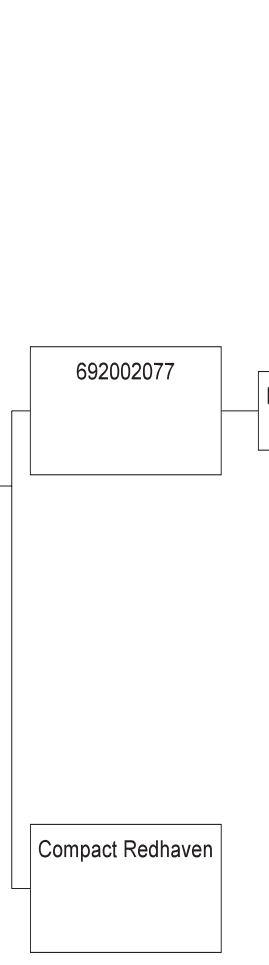

growers in areas where bacterial spot disease is a concern. These cultivars also expand options for growers in the middle to the upper-southern U.S. and other areas of the world with similar climatic conditions.

The names selected continue a series of white-flesh peaches named for noteworthy geographic locations in Arkansas. 'White Rock' is named for White Rock Mountain in Franklin County, Ark., and 'White County' for the county by that name in east-central Arkansas.

\section{Origin}

'White Rock' resulted from a cross of Ark. $371 \times$ Ark. 367 (Fig. 1), and 'White County' resulted from a cross of Ark. $392 \times$ Ark. 433 N (Fig. 2) made at the University of Arkansas Fruit Substation, Clarksville in March 1993. Seedlings were field-planted in Spring 1994 and the original seedling trees of each cultivar were selected in 1997 by J.N.M. and J.R.C. 'White Rock' was tested as Ark. 658 and 'White County' as Ark. 678.

Primary testing of these selections and comparison cultivars was at the Fruit Substation [west-central Arkansas, lat. $35^{\circ} 31^{\prime} 58^{\prime \prime} \mathrm{N}$ and long. 9324'12"W; U.S. Dept. of Agriculture (USDA) hardiness zone 7a; soil type Linker fine sandy loam (Typic Hapludult)]. They were also tested at the Southwest Arkansas Research and Extension Center, Hope [southwest Arkan-

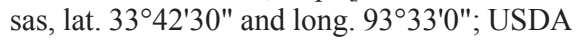
hardiness zone $8 \mathrm{a}$, soil type Bowie fine sandy loam (Fragic Palendult)]. In all testing, trees were either open-center trained and spaced $5.5 \mathrm{~m}$ between trees and rows, or trained to a perpendicular-V system with trees spaced 1.9 $\mathrm{m}$ and rows spaced $5.5 \mathrm{~m}$. Trees were dormant

Fig. 1. Pedigree of 'White Rock' peach.

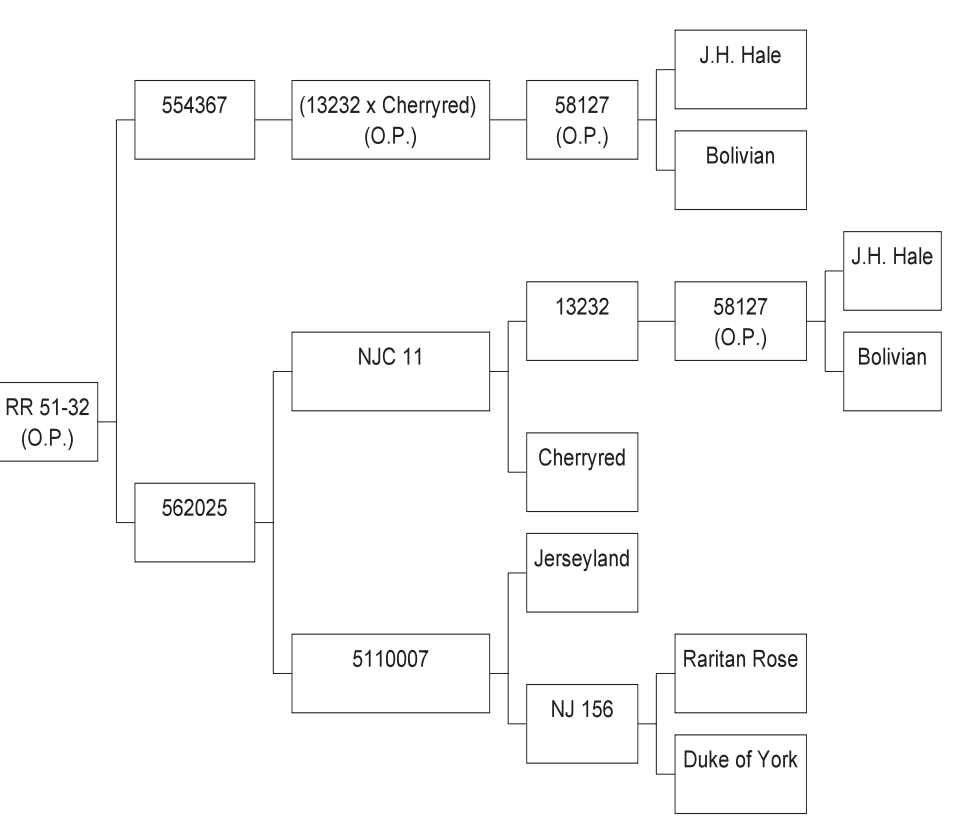




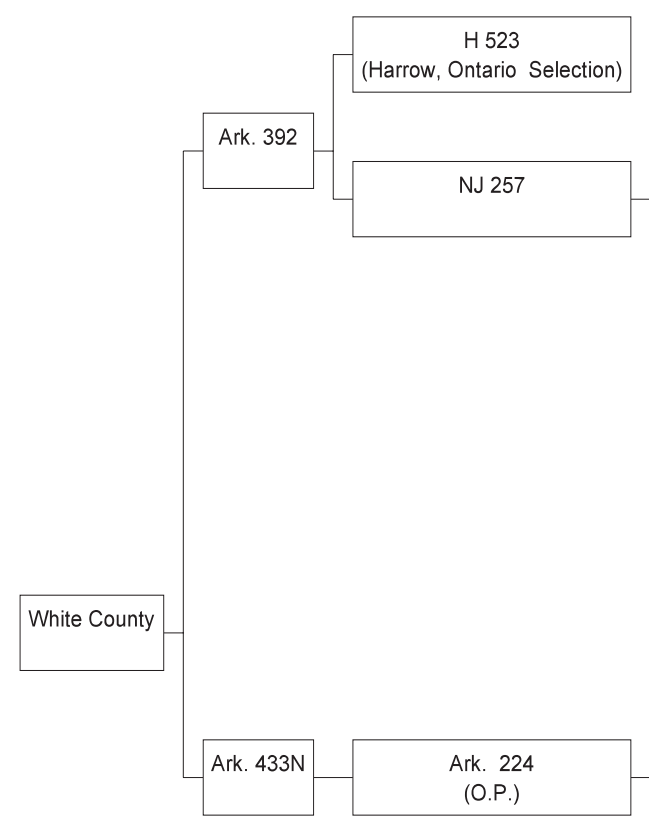

pruned and fertilized annually with either complete or nitrogen fertilizers, and irrigated as needed. Perpendicular- $V$ trees also received one summer pruning, consisting of removing inward-growing shoots, in mid-June of each year. Pests were managed using a program typical for commercial orchards of the area. No bactericides were applied to plantings during testing. Fruit were thinned to a distance of 12 to $15 \mathrm{~cm}$ between fruit after shuck split but before pit hardening each year.

A trial consisting of open-center-trained, two-tree observational plots of 'White Rock' and 'White County' and comparison cultivar 'Redhaven'(Okie, 1998) on 'Lovell' rootstock was maintained at Clarksville and data were collected from these trees or the original selection trees from 1998 through 2003. Dates for $10 \%$ and full bloom (90\% of flowers open) and first harvest were recorded, along with ratings of bloom amount (intensity) on a 1 to 5 scale, with heaviest bloom $=5$ rating. Fruit ratings in the orchard at first harvest were taken from 1998-2003 for shape, firmness, skin color, flesh color, finish, and flavor. Trees were rated for vigor, crop, and health, with an emphasis on bacterial spot severity on leaves or fruit. Rating scale for these fruit and tree variables was 1 to 10 , with $10=$ most desirable. An exception was a rating of 7 to 8 being most desirable for vigor and a rating of 10 indicated excessive vigor. Additionally, a five-fruit sample was collected each year from 1998-2003 and average fruit weight and soluble solids using a bench refractometer (Abbe model, Fisher Scientific, Pittsburg, Pa.) were determined. Also from this sample, split pit percentage was recorded and percent blush on fruit skin was estimated. From this same five-fruit sample, fruit diameter and length were measured along with color. Color coordinates $\left(\mathrm{L}^{*}, \mathrm{a}^{*}\right.$ and $\left.\mathrm{b}^{*}\right)$ for fruit skin (blush and ground color) and flesh color were measured with a chromameter(CR-200 with an $8 \mathrm{~mm}$ aperture, Minolta, Inc., Ramsey, N.J.), and used to determine chroma $\mathrm{C}^{*}$ (McGuire,
Fig. 2. Pedigree of 'White County' peach.
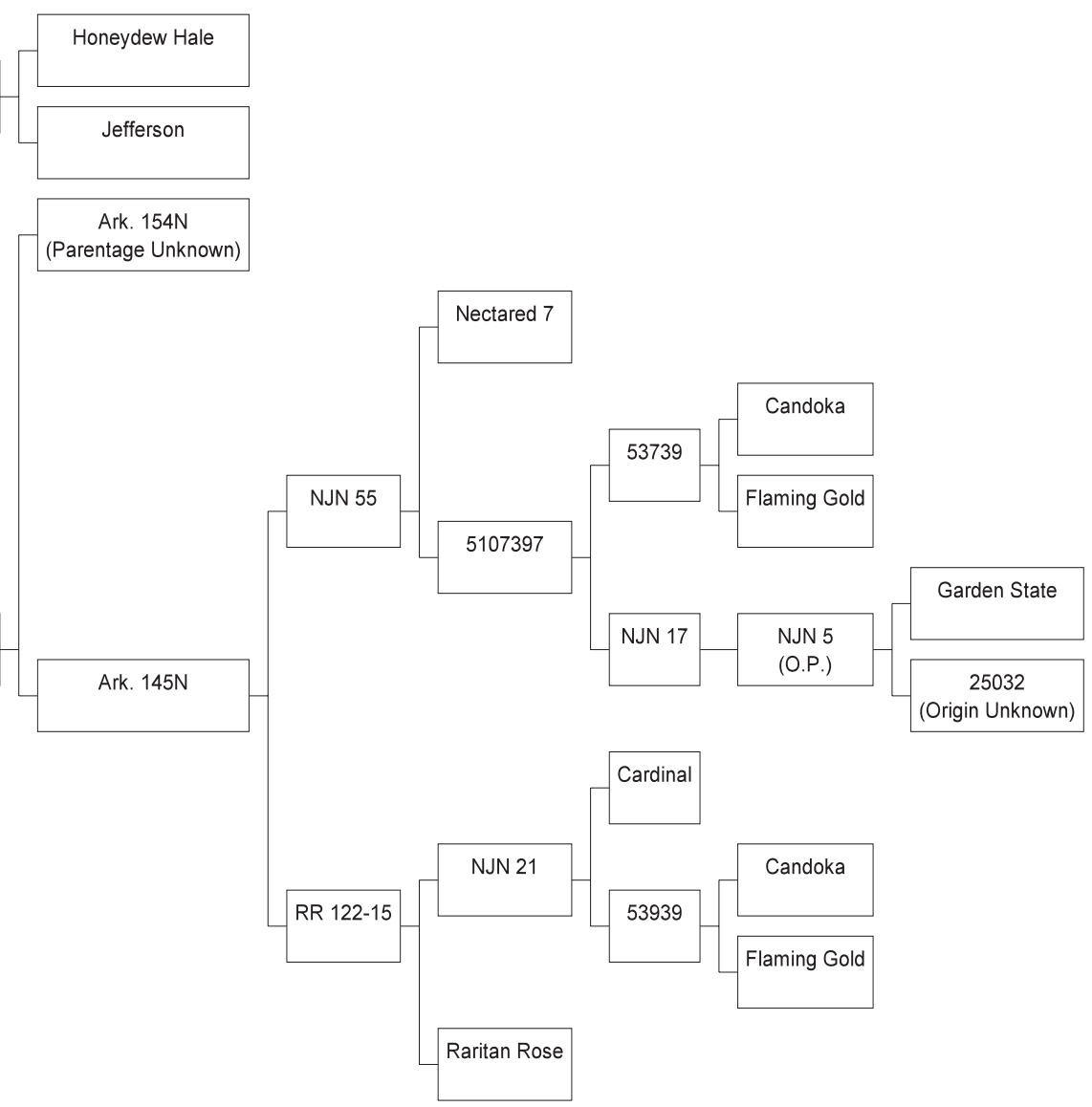

1992). Fruit skin and flesh colors were also assigned Royal Horticultural Society (RHS) Colour Chart designations (Royal Horticultural Society, 1966).

Areplicated trial of perpendicular-V-trained trees of 'White Rock' and 'White County' and standard cultivars Carolina Belle and Summer Pearl on 'Lovell' rootstock was established at Clarksville in 1999. An additional trial of the newly released cultivars and 'White River', 'Nectar', and 'Winblo' (Okie, 1998) was established in 2000 and perpendicular- $\mathrm{V}$ trained. Data collected on these plantings were full bloom and first harvest date, yield, average fruit weight, and rating for bacterial spot

incidence on fruit and leaves. Data were collected in 2001-04 for both plantings. Bacterial spot ratings in this planting were based on a 6-point scale, with $0=$ no bacterial spot and 5 $=$ severe bacterial spot infection with a rating of 3 to 4 commercially acceptable. Areplicated trial at Hope, also trained to a perpendicular-V, including 'White Rock' and 'White County' on 'Lovell' rootstock was established in 2000 and data were collected in 2001-04 for full bloom, yield, fruit weight, and peach scab (caused by Cladosporium carpophilum Thuem.) presence. In each planting, four single-tree replications arranged in a randomized complete block design were utilized, and data for each year were

Table 1. Fruit and plant characteristics of three white-flesh peach cultivars and 'Redhaven' (yellow-flesh) peach from two-tree observational plots, University of Arkansas Fruit Substation, Clarksville, 1998-2003.

Data for fruit weight, soluble solids, firmness, split pits, and percent blush based on a five-fruit sample collected each year at first harvest date. Data are mean values \pm the standard deviation.

\begin{tabular}{|c|c|c|c|c|}
\hline Characteristic & White Rock & White County & White River & Redhaven \\
\hline \multicolumn{5}{|l|}{ Fruit } \\
\hline First harvest date & 25 June \pm 2 & 14 July \pm 3 & 20 July \pm 4 & 30 June \pm 5 \\
\hline Days after full bloom & $90 \pm 2$ & $110 \pm 3$ & $122 \pm 4$ & $99 \pm 5$ \\
\hline Fruit weight $(\mathrm{g})$ & $141.5 \pm 37$ & $257.7 \pm 63$ & $252.3 \pm 43$ & $147.1 \pm 20$ \\
\hline Soluble solids $\%$ & $12.2 \pm 2.1$ & $13.9 \pm 1.8$ & $13.2 \pm 1.0$ & $12.3 \pm 2.6$ \\
\hline Firmness rating ${ }^{z}$ & $8.7 \pm 0.5$ & $9.0 \pm 1.1$ & $7.5 \pm 0.5$ & --- \\
\hline Split pits \% & $0 \pm 0$ & $0 \pm 0$ & $0 \pm 0$ & $5 \pm 10.0$ \\
\hline Percent blush & $72 \pm 9$ & $83 \pm 11$ & $72 \pm 11$ & $79 \pm 17$ \\
\hline \multicolumn{5}{|l|}{ Plant } \\
\hline $10 \%$ bloom date & 20 Mar. \pm 5 & 20 Mar. \pm 5 & 20 Mar. \pm 7 & 16 Mar. \pm 7 \\
\hline Full bloom date & 27 Mar. \pm 3 & 26 Mar. \pm 3 & 26 Mar. \pm 5 & 23 Mar. \pm 7 \\
\hline Bloom amount rating ${ }^{y}$ & $2.8 \pm 0.8$ & $3.0 \pm 0.6$ & $3.5 \pm 0.8$ & $2.8 \pm 0.8$ \\
\hline
\end{tabular}

${ }^{2}$ Firmness rating based on a 1 to 10 scale, with 10 being very firm.

${ }^{\mathrm{y}}$ Based on observation of mature trees at full bloom, using a scale of 1 to 5 , with $5=$ very heavy bloom. 
analyzed separately by analysis of variance and means separated by either LSD or Duncan's multiple range test (SAS Institute, 1989).

Finally, in 2004 a 30 to 50 fruit sample harvested at the early mature stage was provided to Penelope Perkins-Veazie, USDA, Lane, Okla. for postharvest storage and quality evaluation. Samples were transported from Clarksville to Lane, and data were collected on 10 to 26 fruit before storage and a similar number after storage at $5{ }^{\circ} \mathrm{C}, 90 \%$ relative humidity for 7 d. Data collected included percent weight loss during storage, percent total acidity (expressed as citric acid), soluble solids content [measured with a digital refractometer (Atago PR 100, Gardiner, N.Y.)], pH, and fruit firmness [using a fruit pressure tester, 11-mm-diameter probe on peeled fruit (model FT327; Wagner Instruments, Greenwich, Conn.)].

\section{Description and Performance}

Flowers of 'White Rock' and 'White County' are showy and self-fertile. Average 10\% bloom date for both cultivars was 20 Mar. for 1998 through 2003, 4 d later than 'Redhaven' (Table 1). Average full bloom date was 27 Mar. for 'White Rock' and 26 Mar. for 'White County' (Table 1). 'White Rock' and 'White County' bloomed with or near comparison cultivars except for 'Nectar', which bloomed 2 to 3 d later at Clarksville(Tables 2 and 3). Bloom dates were similar for 'White Rock' and 'White County' at Hope (Table 4). Bloom amount (intensity) ratings were near or similar to 'Redhaven' and slightly lower compared to 'White River' at Clarksville (Table 1).

Tree vigor ratings on observational trees averaged 7.2 for 'White Rock' and 7.5 for 'White County' considered an optimum vigor on a 10-point scale (data not shown). Tree health rating for 'White Rock' averaged 8.3 and for 'White County' 8.7 on a 10-point scale, compared to 9.7 for 'White River' (data not shown). A major component of the tree health rating is resistance to bacterial spot, a disease which can be quite severe at Clarksville. 'White Rock' was observed to have light infections of bacterial spot in 2 of 7 years of evaluation in nonreplicated trials and only one year was this of significant concern. This infection occurred on the original selection tree which was growing on a site where the tree was exposed to wind and blown soil which likely contributed to this disease expression. In the replicated trials at Clarksville, 'White Rock' had slight infections of bacterial spot in 2 of 3 years but infection was not a concern for overall leaf or fruit health (Tables 2 and 3). 'White County' was observed to have very slight bacterial spot infection in 4 of 7 years in nonreplicated trials, but at no time was this noted to be of economic significance. Replicated trial data indicated slight infection of either leaves or fruit each year, but again did not impact overall tree health or yield of quality fruit (Tables 2 and 3 ). Among comparison cultivars in the replicated trials, only 'Carolina Belle' and occasionally 'Summer Pearl' were rated as having more bacterial spot infection. Another disease for which ratings were taken was peach scab at
Hope (scab is seldom observed at Clarksville, while bacterial spot is seldom observed at Hope). 'White Rock' was observed to have up to $48 \%$ of its fruit with presence of scab in 2002 ; in this year trees of 'Redhaven' planted in the same row had a $43 \%$ fruit scab presence rating. However, no scab was observed in 2004. This is due largely to more effective fungicide applications in 2004. Scab occurrence observed does indicate that this cultivar is likely more susceptible than other cultivars to this disease. 'White County' had scab noted as present on

fruit in 1 of 3 years at Hope, and only $8 \%$ of the fruit estimated to have lesions in 2002. The other disease seen on 'White Rock' and 'White County' has been occasional brown rot [caused by Monilinia fructicola (G. Wint.) Honey]; however infections were not observed most years and these cultivars are not anticipated to be different in susceptibility than most peach cultivars. A commercial fungicide program is required for disease control for 'White Rock' and 'White County' in areas where brown rot and peach scab occur.

Table 2. Production characteristics of replicated 'White Rock, 'White County', 'Carolina Belle', and 'Summer Pearl' white-flesh peach cultivars, University of Arkansas Fruit Substation, Clarksville, 2001-04. ${ }^{2}$

\begin{tabular}{|c|c|c|c|c|c|c|}
\hline \multirow[b]{2}{*}{ Cultivar } & \multirow{2}{*}{$\begin{array}{c}\text { Full } \\
\text { bloom } \\
\text { date }\end{array}$} & \multirow{2}{*}{$\begin{array}{c}\text { Harvest } \\
\text { date } \\
\text { (first) }\end{array}$} & \multirow{2}{*}{$\begin{array}{l}\text { Yield/ } \\
\text { tree } \\
(\mathrm{kg})\end{array}$} & \multirow{2}{*}{$\begin{array}{l}\text { Fruit } \\
\text { wt } \\
(\mathrm{g})\end{array}$} & \multicolumn{2}{|c|}{$\begin{array}{c}\text { Bacterial } \\
\text { spot rating }\end{array}$} \\
\hline & & & & & Leaves & Fruit \\
\hline \multicolumn{7}{|l|}{2001} \\
\hline White Rock & 2 Apr. $a^{x}$ & 3 July & $12.1 \mathrm{~b}$ & $115.6 \mathrm{~b}$ & $0.6 \mathrm{~b}$ & $1.6 \mathrm{a}$ \\
\hline White County & 2 Apr. a & 21 July & $16.9 \mathrm{ab}$ & $140.0 \mathrm{a}$ & $0.3 \mathrm{~b}$ & $0.8 \mathrm{a}$ \\
\hline Carolina Belle & 1 Apr. a & 20 July & $13.5 \mathrm{ab}$ & $144.4 \mathrm{a}$ & $2.0 \mathrm{a}$ & $1.0 \mathrm{a}$ \\
\hline Summer Pearl & 2 Apr. a & 1 Aug. & $11.4 \mathrm{~b}$ & $109.8 \mathrm{~b}$ & $0.0 \mathrm{~b}$ & $0.7 \mathrm{a}$ \\
\hline \multicolumn{7}{|l|}{2002} \\
\hline White Rock & 30 Mar. a & 7 July & $15.8 \mathrm{a}$ & $156.2 \mathrm{~b}$ & $1.3 \mathrm{a}$ & $1.0 \mathrm{a}$ \\
\hline White County & 30 Mar. a & 17 July & $19.2 \mathrm{a}$ & $234.5 \mathrm{a}$ & $0.0 \mathrm{~b}$ & $0.5 \mathrm{a}$ \\
\hline Carolina Belle & 29 Mar. a & 16 July & $11.8 \mathrm{a}$ & $192.6 \mathrm{~b}$ & $0.0 \mathrm{~b}$ & $0.8 \mathrm{a}$ \\
\hline Summer Pearl & 31 Mar. a & 1 Aug. & $13.5 \mathrm{a}$ & $131.2 \mathrm{c}$ & $1.3 \mathrm{a}$ & $1.3 \mathrm{a}$ \\
\hline \multicolumn{7}{|l|}{2003} \\
\hline White Rock & 25 Mar. a & 29 June & $25.5 \mathrm{a}$ & $126.8 \mathrm{~b}$ & $0.0 \mathrm{~b}$ & $0.0 \mathrm{~b}$ \\
\hline White County & 23 Mar. a & 12 July & $23.4 \mathrm{a}$ & $154.8 \mathrm{a}$ & $0.0 \mathrm{~b}$ & $0.0 \mathrm{~b}$ \\
\hline Carolina Belle & 24 Mar. a & 12 July & $20.8 \mathrm{a}$ & $172.1 \mathrm{a}$ & $1.5 \mathrm{a}$ & $0.3 \mathrm{~b}$ \\
\hline Summer Pearl & 24 Mar. a & 24 July & $11.0 \mathrm{~b}$ & $127.9 \mathrm{~b}$ & $1.5 \mathrm{a}$ & $2.5 \mathrm{a}$ \\
\hline \multicolumn{7}{|l|}{2004} \\
\hline White Rock & 23 Mar. b & 28 June & $20.8 \mathrm{ab}$ & $138.8 \mathrm{~b}$ & $0.0 \mathrm{~b}$ & $0.0 \mathrm{a}$ \\
\hline White County & 22 Mar. ab & 11 July & $26.8 \mathrm{a}$ & $218.8 \mathrm{a}$ & $0.0 \mathrm{~b}$ & $0.0 \mathrm{a}$ \\
\hline Carolina Belle & 21 Mar. a & 13 July & $24.3 \mathrm{a}$ & $224.5 \mathrm{a}$ & $2.0 \mathrm{a}$ & $0.0 \mathrm{a}$ \\
\hline Summer Pearl & 22 Mar. ab & 23 July & $17.2 \mathrm{~b}$ & $151.0 \mathrm{~b}$ & $1.3 \mathrm{a}$ & $0.0 \mathrm{a}$ \\
\hline
\end{tabular}

zPlanting established in 1999.

${ }^{y}$ Scale of 0 to 5 , with $0=$ no bacterial spot lesions observed on leaves or fruit; $5=$ severe infection.

${ }^{\mathrm{x}}$ Mean separation within columns and years by LSD, $P<0.05$.

Table 3. Production characteristics of replicated 'White Rock, 'White County', 'White River', and 'Nectar' white flesh, and 'Winblo' yellow flesh peach cultivars, University of Arkansas Fruit Substation, Clarksville, 2001-04. ${ }^{\mathrm{z}}$

\begin{tabular}{|c|c|c|c|c|c|c|}
\hline \multirow[b]{2}{*}{ Cultivar } & \multirow{2}{*}{$\begin{array}{c}\text { Full } \\
\text { bloom } \\
\text { date }\end{array}$} & \multirow{2}{*}{$\begin{array}{l}\text { Harvest } \\
\text { date } \\
\text { (first) }\end{array}$} & \multirow{2}{*}{$\begin{array}{c}\text { Yield/ } \\
\text { tree } \\
(\mathrm{kg})\end{array}$} & \multirow{2}{*}{$\begin{array}{c}\text { Fruit } \\
\text { wt } \\
(\mathrm{g})\end{array}$} & \multicolumn{2}{|c|}{$\begin{array}{c}\text { Bacterial } \\
\text { spot rating }\end{array}$} \\
\hline & & & & & Leaves & Fruit \\
\hline \multicolumn{7}{|l|}{2001} \\
\hline White Rock & 28 Mar. $^{\mathrm{x}}$ & 1 July & $2.1 \mathrm{a}$ & $100.8 \mathrm{~b}$ & $0.0 \mathrm{a}$ & $0.8 \mathrm{a}$ \\
\hline White County & 29 Mar. a & 20 July & $0.6 \mathrm{~b}$ & $183.4 \mathrm{a}$ & $0.3 \mathrm{a}$ & $0.5 \mathrm{a}$ \\
\hline White River & 29 Mar. a & 23 July & $0.5 \mathrm{~b}$ & $216.2 \mathrm{a}$ & $0.1 \mathrm{a}$ & $0.2 \mathrm{a}$ \\
\hline Nectar & 1 Apr. b & 18 July & $0.7 \mathrm{~b}$ & $127.4 \mathrm{~b}$ & $0.8 \mathrm{a}$ & $0.3 \mathrm{a}$ \\
\hline Winblo & --- & --- & --- & --- & --- & --- \\
\hline \multicolumn{7}{|l|}{2002} \\
\hline White Rock & 1 Apr. b & 5 July & $6.9 \mathrm{a}$ & $148.2 \mathrm{~b}$ & $0.0 \mathrm{a}$ & $0.3 \mathrm{a}$ \\
\hline White County & 30 Mar. a & 20 July & $9.1 \mathrm{a}$ & $162.0 \mathrm{ab}$ & $0.0 \mathrm{a}$ & $0.3 \mathrm{a}$ \\
\hline White River & 29 Mar. ab & 28 July & $7.3 \mathrm{a}$ & $192.3 \mathrm{a}$ & $0.9 \mathrm{a}$ & $0.3 \mathrm{a}$ \\
\hline Nectar & 2 Apr. b & 22 July & $1.3 \mathrm{~b}$ & $175.2 \mathrm{ab}$ & $0.4 \mathrm{a}$ & $0.0 \mathrm{a}$ \\
\hline Winblo & 30 Mar. ab & 18 July & $2.2 \mathrm{~b}$ & $162.1 \mathrm{ab}$ & $0.0 \mathrm{a}$ & $0.0 \mathrm{a}$ \\
\hline \multicolumn{7}{|l|}{2003} \\
\hline White Rock & 24 Mar. a & 1 July & $18.9 \mathrm{a}$ & $117.9 \mathrm{~b}$ & $0.0 \mathrm{a}$ & $0.0 \mathrm{a}$ \\
\hline White County & 23 Mar. a & 13 July & $20.4 \mathrm{a}$ & $136.5 \mathrm{a}$ & $0.3 \mathrm{a}$ & $0.0 \mathrm{a}$ \\
\hline White River & 24 Mar. a & 19 July & $15.2 \mathrm{a}$ & $122.6 \mathrm{ab}$ & $0.0 \mathrm{a}$ & $0.0 \mathrm{a}$ \\
\hline Nectar & 27 Mar. b & 14 July & $7.1 \mathrm{~b}$ & $129.5 \mathrm{ab}$ & $0.1 \mathrm{a}$ & $0.3 \mathrm{a}$ \\
\hline Winblo & 24 Mar. a & 12 July & $17.6 \mathrm{a}$ & $138.6 \mathrm{a}$ & $0.0 \mathrm{a}$ & $0.0 \mathrm{a}$ \\
\hline \multicolumn{7}{|l|}{2004} \\
\hline White Rock & 23 Mar. a & 30 June & $18.3 \mathrm{~b}$ & 135.1 & $0.0 \mathrm{~b}$ & $0.0 \mathrm{a}$ \\
\hline White County & 22 Mar. a & 15 July & $26.3 \mathrm{a}$ & 196.1 & $0.0 \mathrm{~b}$ & $0.0 \mathrm{a}$ \\
\hline White River & 22 Mar. a & 18 July & $12.2 \mathrm{~b}$ & 239.7 & $0.0 \mathrm{~b}$ & $0.0 \mathrm{a}$ \\
\hline Nectar & 25 Mar. b & 16 July & $4.1 \mathrm{c}$ & 185.5 & $0.8 \mathrm{a}$ & $0.0 \mathrm{a}$ \\
\hline Winblo & 22 Mar. a & 14 July & $18.5 \mathrm{~b}$ & 188.4 & $0.0 \mathrm{~b}$ & $0.0 \mathrm{a}$ \\
\hline
\end{tabular}

zPlanting established in 2000.

${ }^{\text {y }}$ Scale of 0 to 5 , with $0=$ no bacterial spot lesions observed on leaves or fruit; $5=$ severe infection.

${ }^{\mathrm{x}}$ Mean separation within columns and years by LSD, $P<0.05$. 
Chilling requirement of these cultivars has not been determined but is probably near $800 \mathrm{~h}$ below $7{ }^{\circ} \mathrm{C}$ based on observations of budbreak and bloom in comparative plantings with test cultivars of known chill requirement. These cultivars have not been tested in colder locations than Arkansas thus bud hardiness has not been determined. Leaf glands for both cultivars are reniform with two per leaf for 'White Rock' and average of four per leaf for 'White County'.

'White Rock' was first ripe on average 25 June at Clarksville (average $90 \mathrm{~d}$ after full bloom) in observational plots (Table 1), but first harvest in replicated trials (Clarksville) ranged from 29 June to 7 July (Tables 2 and 3 ). This may have been due to the very firm flesh of this cultivar, which can indicate to a harvester the fruit is not ripe since it is very firm at first ripe. Ripening date was about 5 $\mathrm{d}$ earlier than 'Redhaven' and $25 \mathrm{~d}$ before 'White River' (Table 1). 'White County' first ripe date averaged 14 July (average $110 \mathrm{~d}$ after full bloom) (Table 1) and ranged from 12 to 21 July in replicated trials at Clarksville (Tables 2 and 3). First ripe date on average was $6 \mathrm{~d}$ before 'White River'. Crop ratings on observation trees had a mean rating for 6 years of 9.2 for 'White Rock' and 9.0 for 'White County', among the highest ratings for any genotypes in the program during this time (data not shown). Yields for 'White Rock' were consistently high in replicated trials and comparable to the higher yielding cultivars (Tables 2-4). 'White County' had consistent yields also, usually the highest or among the highest in all comparisons (Tables 2-4). No crop losses or reductions due to frost were experienced during the evaluation period for either cultivar. Average fruit weight at Clarksville for 'White Rock' was $141.1 \mathrm{~g}$, similar to 'Redhaven'(Tables 1-4). It was observed that this cultivar commonly set a very heavy crop, and if not well-thinned small fruit size could result. Conversely, well-thinned trees had larger fruit and this indicates that early and thorough thinning are critical for 'White Rock'. 'White County' was heavier than 'White Rock' in many comparisons, averaging $257.7 \mathrm{~g}$ on observational trees (Table 1). In replicated trials, 'White County' was among the larger fruit in most comparisons (Tables 2-4).

Fruit of 'White Rock' are round to oval and averaged $6.4 \mathrm{~cm}$ in length and diameter, and usually have a pronounced suture but were without a pronounced tip. Fruit shape ratings ranged from 7 to 8 (data not shown). Split pits were observed one year in observations at Clarksville and Hope but none were recorded in fruit samples evaluated (Table 1). Fruit skin color and finish ratings were good for 'White Rock', usually 7 to 8 (data not shown). Percent blush on the fruit skin averaged $72 \%$, the same as 'White River' and just under that of 'Redhaven'(Table 1). It was observed that fruit exposed to sunlight had substantially higher red on the skin surface, thus management practices including summer pruning should substantially enhance this characteristic. Background or ground color was noted to usually be an attractive cream color at maturity with green color not retained. The average ground color values for 6 years for 'White Rock' were L* $=72.3$ (the higher the $\mathrm{L}$ value the lighter the sample); $a^{*}=4.3$ (the higher the a value the redder the sample); $b^{*}=25.3$ (the higher the $\mathrm{b}$ value the more yellow the sample), and an RHS designation of Yellow Group (11B). The red blush or over color of the skin averaged $\mathrm{L}^{*}=42.3 ; \mathrm{a}^{*}=38.1 ; \mathrm{b}^{*}=18.7$, and a RHS designation of Red Group (46A). Fruit were observed to mature evenly, although firmness and sugar levels were not measured on various locations on fruit to verify this observation. Finish ratings reflect uniformity of the fruit surface and higher ratings indicate smooth fruit surface free of cracking, freckling and bacterial spot lesions. 'White Rock' had very good finish ratings, averaging 8.0 on a 10-point scale (data not shown). Fruit have also been observed to hold very well on the trees, often remaining after full maturity was achieved.

Fruit firmness rating for 'White Rock' averaged 8.7 and exceeded that for 'White River' (Table 1). The flesh of 'White Rock' is nonmelting and does not soften substantially at full maturity; overmature fruit often remain firm even after dropping from the tree. 'White Rock' is a cling-type fruit. Flesh color is near all white, with occasional red in the flesh around the pit. Average flesh color values for 6 years were $L^{*}=71.4 ; a^{*}=-2.3 ; b^{*}=15.9$, and a RHS designation Yellow-White Group (158C). Flesh color ratings averaged 8.0, indicating an attractive flesh lacking defects such as green in the flesh or excess presence of red. Flavor for 'White Rock' has been consistently rated high by the authors averaging 7.5 over 6 years (data not shown). The fruit is a low-acid type with a very light white peach flavor. Soluble solids averaged $12.2 \%$ (Table 1 ).

'White County' fruit are mostly round to slightly oval and averaged $7.8 \mathrm{~cm}$ in length and diameter, and usually have a pronounced suture. In 2004 at Hope fruit were seen with small tips on the distal ends of the fruit. Fruit shape ratings ranged from 7 to 8 (data not shown). Split pits were not observed on 'White County' (Table 1). Fruit skin color and finish ratings were good for 'White County', usually 7 to 8 (data not shown). Percent blush on the fruit skin averaged $83 \%$, more than comparison cultivars (Table 1). Management practices including summer pruning should substantially enhance this characteristic. Background or ground color was noted to usually be an attractive cream color at maturity. The average ground color values for 6 years for 'White County' were $L^{*}=69.3 ; a^{*}=9.4 ; b^{*}=27.6$, and a RHS designation of Yellow-White Group (158A). The red blush or over color of the skin averaged $L^{*}=36.1 ; a^{*}=32.7 ; b^{*}=13.8$, and a RHS designation of Red Group (53B). Fruit were observed to mature evenly. 'White County' had good finish ratings, averaging 7.7 on a 10-point scale (data not shown).

Fruit firmness rating for 'White County' averaged 9.0 and exceeded that for 'White River' (Table 1). The flesh of 'White County' is melting and is very firm until full maturity when it softens substantially. 'White County' is freestone. Flesh color is usually fully white, with occasional red in the flesh around the pit. Average flesh color values for 6 years were $\mathrm{L}^{*}=69.7 ; \mathrm{a}^{*}=2.0 ; \mathrm{b}^{*}=15.3$, and a RHS designation Yellow-White Group (158C). Flesh color ratings averaged 8.0, indicating an attractive flesh lacking defects such as green in the flesh or excess presence of red. Flavor of 'White County' has been consistently rated high by the authors averaging 7.2 over 6 years (data not shown). The fruit is a low-acid type with a very distinct white peach flavor. Soluble solids averaged $13.9 \%$ (Table 1$)$.

Table 4. Bloom date, yield, fruit weight, and scab lesions of 'White Rock'and 'White County fresh-market peach cultivars grown at the Southwest Research and Extension Center, Hope, Ark. ${ }^{z}$

\begin{tabular}{|c|c|c|c|c|}
\hline Cultivar & $\begin{array}{l}\text { Full } \\
\text { bloom } \\
\text { date }\end{array}$ & $\begin{array}{l}\text { Yield/ } \\
\text { tree } \\
(\mathrm{kg})\end{array}$ & $\begin{array}{l}\text { Fruit } \\
\text { wt } \\
(\mathrm{g})\end{array}$ & $\begin{array}{l}\text { Estimated percent } \\
\text { fruit with } \\
\text { scab lesions }\end{array}$ \\
\hline \multicolumn{5}{|l|}{2002} \\
\hline White Rock & 19 Mar. $\mathrm{a}^{\mathrm{y}}$ & $4.5 \mathrm{a}$ & $137.3 \mathrm{~b}$ & $48^{x}$ \\
\hline White County & 19 Mar. a & $4.3 \mathrm{a}$ & $183.0 \mathrm{a}$ & 8 \\
\hline \multicolumn{5}{|l|}{2003} \\
\hline White Rock & 23 Mar. a & $17.5 \mathrm{a}$ & $96.1 \mathrm{a}$ & 45 \\
\hline White County & 22 Mar. a & $26.9 \mathrm{a}$ & $100.6 \mathrm{a}$ & 0 \\
\hline \multicolumn{5}{|l|}{2004} \\
\hline White Rock & 17 Mar. a & $18.6 \mathrm{a}$ & $135.0 \mathrm{a}$ & 0 \\
\hline White County & 15 Mar. a & $11.8 \mathrm{a}$ & $140.0 \mathrm{a}$ & 0 \\
\hline
\end{tabular}

2Planting established in 2000

${ }^{y}$ Mean separation within columns and years by LSD, $P \leq 0.05$.

xPeach scab estimates made on harvested fruit; data are observational and not statistically analyzed.

Table 5. Changes in 'White Rock', 'White County', and 'Loring' peaches after storage at $5{ }^{\circ} \mathrm{C}$ for $7 \mathrm{~d}$; fruit are from a single harvest at early fruit maturity and due to time of maturity differences 'White Rock' was not stored at the same time as the other cultivars.

\begin{tabular}{|c|c|c|c|c|c|c|}
\hline Cultivar & $\begin{array}{l}\text { Storage } \\
\text { period } \\
\text { (d) }\end{array}$ & $\begin{array}{l}\text { Fruit } \\
\text { (no.) }\end{array}$ & $\begin{array}{l}\mathrm{Wt} \\
\text { loss } \\
(\%)\end{array}$ & $\begin{array}{c}\text { Total } \\
\text { acidity } \\
(\%)\end{array}$ & $\mathrm{pH}$ & $\begin{array}{c}\text { Avg } \\
\text { firmness } \\
(\mathrm{kg})\end{array}$ \\
\hline \multirow[t]{2}{*}{ White Rock } & 0 & 21 & -- & 0.20 & 4.8 & 1.62 \\
\hline & 7 & 26 & 0.8 & 0.30 & 4.4 & 2.90 \\
\hline \multirow{2}{*}{ White County } & 0 & 12 & --- & 0.18 & 4.7 & 1.17 \\
\hline & 7 & 20 & 0.8 & 0.17 & 4.8 & 0.99 \\
\hline \multirow[t]{2}{*}{ Loring } & 0 & 10 & --- & 0.59 & 3.7 & 0.78 \\
\hline & 7 & 22 & 0.7 & 0.53 & 3.8 & 0.54 \\
\hline
\end{tabular}


Fruit samples evaluated on day 0 and $7 \mathrm{~d}$ after storage at $5{ }^{\circ} \mathrm{C}$ indicated similar weight loss during storage among cultivars with different trends for other variables depending on cultivar (Table 5). The lower acidity of 'White Rock' and 'White County' are reflected in the data, with acidity $\leq 0.5$ than that of 'Loring', a standard acidity, yellow-flesh, freestone cultivar. The higher observed firmness of 'White Rock', and to some extent 'White County' is reflected in the data. 'White Rock' data indicated firmer fruit after storage for $7 \mathrm{~d}$ compared to $0 \mathrm{~d}$; however this higher firmness value may have been due to the 7-d group of fruit being firmer than the 0 -d fruit at the time of selection of fruit for storage. Sweetness and acidity changed little with storage (sweetness data not shown).

The outstanding characteristics of 'White
Rock'and White County' are their high yields of high-quality, low-acid, attractive, whiteflesh fruit. Additionally they have adequate commercial bacterial spot resistance. These cultivars are recommended for trial where other medium- to high-chill peaches developed in the eastern U.S. are grown.

\section{Availability}

Applications for U.S. plant patents have been filed for 'White Rock' and 'White County'. Alist of nurseries licensed to propagate and sell these cultivars will be available from J.R.C., 316 Plant Science, Dept. of Horticulture, Univ. ofArkansas, Fayetteville, AR 72701.Alimited amount of budwood is available for research and evaluation purposes and requests can be sent to J.R.C., 316 Plant Science, Dept. of
Horticulture, Univ. of Arkansas, Fayetteville, AR 72701 or jrclark@uark.edu.

\section{Literature Cited}

Clark, J.R. and J.N. Moore. 2003. 'White River' peach. HortScience 38:1257-59.

Clark, J.R., J.N. Moore, C.R. Rom, K.R. Woodburn, B. Blackburn, and A. Allen. 1999. Arkansas fruit breeding update: New cultivars of small and tree fruit. Proc. 18th Annu. Hort. Ind. Show p. $8-10$.

McGuire, R.G. 1992. Reporting of objective color measurements. HortScience 27:1254-1255.

Okie, W.R. 1998. Handbook of peach and nectarine varieties. USDA Hndbk. 714.

Royal Horticultural Society. 1966. Royal Horticultural Society colour chart. Royal Hort. Soc., London and Flower Council of Holland, Leiden.

SAS Institute. 1989. SAS/STAT user's guide, version 6. vol. 2. SAS Inst. Inc., Cary, N.C. 